\title{
ANALYSIS OF FACTORS AFFECTING THE IMPLEMENTATION OF COMPUTER-BASED ACCOUNTING INFORMATION SYSTEM ON SMALL AND MEDIUM ENTERPRISES
}

\author{
Siti Nur Azizah \\ Economics and Business Faculty, Universitas Muhammadiyah Purwokerto, Indonesia \\ Jalan Raya Dukuh Waluh, Purwokerto 53181 Indonesia, Phone +62-281-636751 \\ Correspondence E-mail: sn.azizahump@yahoo.com
}

Received: June 2017; Accepted: October 2017

\begin{abstract}
The objective of the research is to examine some factors that influence implementation computer-based accounting information system on Small and Medium Enterprises (SMEs). The study is based on the model proposed by Davis (1989), they are perceived usefulness, perceived ease of use, the attitude toward using, intention in use and actual usage that includes in Technology Acceptance Model (TAM) theory. Computer-based accounting information system in this study was measured by usage of Point of Sales (POS) system. This study used data obtained from individual perception of information system user in Dieng-Mart Swalayan collected from 33 questionnaires. The data were analyzed by regression use SPSS 16.0 software. Study result shows that the implementation of Computer-based accounting information system is influenced by perceived ease of use and attitude toward using which are included in TAM theory.

Keywords: Technology Acceptance Model (TAM), Point of Sales (POS) system, Small and Medium Enterprises (SMEs).
\end{abstract}

JEL Classification: M15, M21, L32

Abstrak: Tujuan dari penelitian ini adalah untuk menguji beberapa faktor yang mempengaruhi
penerapan sistem informasi akuntansi berbasis komputer pada Usaha Kecil dan Menengah
(UKM). Penelitian ini didasarkan pada model yang diajukan oleh Davis (1989), mereka dianggap
bermanfaat, dirasakan mudah digunakan, sikap terhadap penggunaan, niat dalam penggunaan
dan penggunaan aktual yang termasuk dalam teori Teknologi Model Penerimaan (TAM). Sistem
informasi akuntansi berbasis komputer dalam penelitian ini diukur dengan penggunaan sistem
Poin Penjualan (POS). Penelitian ini menggunakan data yang diperoleh dari persepsi individu
pengguna sistem informasi di Dieng-Mart Swalayan yang dikumpulkan dari 33 kuesioner. Data
dianalisis dengan regresi menggunakan software SPSS 16.0. Hasil penelitian menunjukkan
bahwa penerapan sistem informasi akuntansi berbasis komputer dipengaruhi oleh perceived ease
of use dan attitude terhadap penggunaan yang termasuk dalam teori TAM. Kata kunci: Teknologi Model Penerimaan (TAM), Sistem Poin Penjualan (POS), Usaha Kecil dan Menengah (UKM).

Klasifikasi JEL: M15, M2, L32 


\section{INTRODUCTION}

Small and Medium Enterprises (SMEs) is a business unit managed by the community, either in the form of private businesses, business groups, or the family business that is still on a small scale. SMEs have a strategic role in national economic development, not only contributing to national economic growth SMEs, but also absorb unemployed labor in large numbers.

In the current era of globalization, especially SMEs are required to make changes in order to improve their competitiveness. In addition, the utilization of information technology in a business field is also growing rapidly, so that it causes an entity seeks to apply technology and information systems used to process and submit information effectively and efficiently in order to support the business processes and improve the quality of service (Sari, 2011).

One of the SMEs interesting to be examined is Dieng-Mart Swalayan in Banyumas Regency. Based on direct observation, DiengMart Swalayan is one of the medium-sized business sector that is not as Alfamart or Indomart which are in form of franchises. So, Dieng-Mart Swalayan becomes a SME that conduct its business in a high competition business sector.

Based on several problems in Dieng Mart Swalayan, it needs to be examined the factors affecting the implementation of Computer Based Accounting Information Systems at Dieng-mart Swalayan Banyumas. Hopefully, the result of this research will be further utilized by businesses to develop their business. As according to Rahmana (2009) that the uses of information technology and information systems are able to improve business transformation through speed, accuracy and efficiency of information exchange in large numbers.

Previous researches conducted in many countries have shown some different conclusions. Bugembe (2010) research conducted in Uganda proved that there was correlation between perceived ease of use and attitudes towards using the system. The similar research conducted by Sriwidharmanely and Vina (2012) in Bengkulu, Indonesia stated that perceived ease of use has no effect to attitude towards using.

Previous researches have some limitations. The research of Bugembe (2010) conducted in Uganda, the study of Sriwidharmanely and Vina (2012) in Bengkulu and research conducted by Amidu et al. (2011) in Ghana are only regionally research which are cannot generalized elsewhere. Variable development also necessary to conduct related to the research of Allahyari et al. (2012) which only use perceived usefulness, perceived ease of use and social factor toward actual usage. Therefore, TAM development also needs to be done by adding several TAM variables such as attitudes towards the using and intention of use.

Based on the research gap such as the difference of the results of the similar studies, the limitations of previous studies and the structure of concepts that need to be followed, it is necessarily to re-examine the factors predicted to be able to affect the implementation of computer-based Accounting Information Systems on Small and Medium Enterprises (SMEs) on Dieng-Mart Swalayan in Banyumas.

TAM (Technology Acceptance Model) was first introduced by Davis in 1986. TAM is a development of the TRA (Theory of Reasoned Action), which is a model of technology acceptance assessment that identifies an individual's level of acceptance of the technology. The main objective of TAM as stated by Davis is to explain the factors that influence the acceptance of Information Technology with a broad range of information technology and the population of users. 


\section{RESEARCH METHOD}

\section{Data and Source}

This research was categorized as quantitative research conducted by a survey method in branch offices of "Dieng-Mart Swalayan" in Banyumas regency. The object of this research is the implementation of a computer-based accounting information system in" Dieng-Mart Swalayan" in Banyumas Regency by considering perceived usefulness, perceived ease of use, attitude toward using, and intention to use factors.

\section{Sampling Technique}

The population of this research was every single employee in the "Dieng Mart Swalayan" in Banyumas Regency. Sample size was measured using a saturated-sample method that means whole population was used as the sample of research.

\section{Operational Definition of Variable}

(1) Perceived Usefulness (X1): the individual perception that POS system usage will increase his/her productivity, performance and make working process becomes more efficient. (2) Perceived Ease of Use (X2): the individual perception that POS system can be used easily and free of problems. (3) Attitude toward Using (X3): user's attitudes towards the using of POS system in the form of positive or negative perception as a result when someone use the system in his/her work. (4) Intention to use (X4): can be shown by how individual learning way or suggestion to the others related to the system and demand of POS system development. (5) Actual usage (Y): the real of POS system usage in individual's job. It is used as the measurement of implementation of computer-based accounting information system.

\section{Analysis Tool}

This research used the multiple regression and simple regression analysis to analyze the influence of the independent variables on the dependent variables. (Suliyanto, 2011: 53). The equations used in this research were:

$\mathrm{Y} 1=\mathrm{a}+\mathrm{b} 1 \mathrm{X} 1+\mathrm{b} 2 \mathrm{X} 2+\mathrm{e}$

$\mathrm{Y} 2=\mathrm{a}+\mathrm{b} 3 \mathrm{Y} 1+\mathrm{e}$

$\mathrm{Y} 3=\mathrm{a}+\mathrm{b} 4 \mathrm{Y} 2+\mathrm{e}$

Where :

$\mathrm{Y} 1=$ attitude; $\mathrm{Y} 2=$ intention to use; $\mathrm{Y} 3$ = actual usage; $\alpha=$ constant; $\beta 1=$ regression coefficient of perceived usefulness; $\beta 2=$ regression coefficient of perceived ease of use; $\beta 3=$ regression coefficient of attitude; $\beta 4=$ regression coefficient of intention to use; $\mathrm{X} 1=$ perceived usefulness; $\mathrm{X} 2=$ perceived ease of use; e $=$ error.

\section{RESULTS AND DISCUSSION}

Table 11. Hypothesis Testing Result

\begin{tabular}{cccc}
\hline Hypothesis & Beta & Sig & Conclusion \\
\hline H1 & 0.149 & 0.211 & rejected \\
\hline H2 & 0.194 & 0.013 & accepted \\
\hline H3 & 0.513 & 0.025 & accepted \\
\hline H4 & -0.156 & 0.151 & rejected \\
\hline
\end{tabular}

Hypothesis 1 stated that the perceived usefulness affects attitudes toward using on implementation of computer-based accounting information system. Table 11 shows the perceived usefulness variable has a sig. value of 0.211 where the alpha value is the above figures taken, at 0.05 . The regression coefficient is 0.149 , so that the hypothesis 1 is not acceptable. It means that perceived usefulness has no effect on attitudes toward using a computer-based accounting information system. This is not consistent with the results of research conducted by Yuadi (2009), Awosejo et al. (2013), Bugembe (2010) and Sari (2014) which concluded that the perceived usefulness variable affects attitudes towards using of a computer-based accounting information system. The causal that makes difference from previous studies is the respondents who seems have lack of knowledge. This is evident from the characteristics of the respondents where 
$83 \%$ of the new accounting training earn 1-3 times and $85 \%$ of the respondents also recently been getting computer training only 1-3 times. The low amount of training received by the respondents is resulted in the lack of knowledge of the respondents about the system. This is resulted in a variable bias on perceived usefulness that is felt by the respondents that the relationship between variables perceived usefulness and attitude toward using variable are not significantly associated.

Hypothesis 2 stated that perceived ease of use affects attitudes toward using on implementation of computer-based accounting information system. Table 11 shows the perceived ease of use has sig. value of 0.013 (below alpha 0.05) with a regression coefficient of 0.194 , so that the hypothesis 2 is accepted. It means that the perceived ease of use influences the attitudes in use of a computer-based accounting information system. This is consistent with studies of Yuadi (2009), Awosejo et al (2013), Bugembe (2010) and Sari (2014). It suggested that if a system is easy to use, there is the tendency for respondents to react positively toward the new technology itself.

Hypothesis 3 stated that attitude toward using affects intention to use on implementation of computer-based accounting information system. Table 11 shows the attitude has sig. value of 0.025 (below alpha 0.05 ) with a regression coefficient of 0.513 . So, hypothesis 3 is accepted. It means that attitudes toward using affects intention in the use of a computerbased accounting information system. This result is consistent with research of Davis (1989) and Wibowo (2007). This means that respondents' positive attitude towards a system affects the intention in using a computer-based accounting information system. Conversely, negative attitudes of respondents toward the usage of computer-based accounting information system causes a lack of intention of the respondent that finally suggests the tendency of do not want to use a new system.

Hypothesis 4 stated that the intention to use affects actual usage on implementation of computer-based accounting information system. Table 11 shows that the intention to use has a sig. value of 0.151 (above alpha value of 0.05 ) with a negative regression coefficient of 0.156. So, hypothesis 4 is not acceptable. It means that the intention to use has no effect on the actual usage of a computer-based accounting information system. This result does not support previous research conducted by Sriwedharmanely and Vina (2012) and Awosejo et al. (2013). Thing that causes the difference from previous studies is the respondents of this research that have a position as employees who must obey the leader. This leads to a condition in which the decision whether the respondent wants to use or not an accounting information system technology depends on the management's decision not in the respondent's judgment.

\section{CONCLUSIONS}

Based on the evidence obtained from the results of this research, it can be concluded that:

1. Perceived usefulness does not affect attitudes toward using on implementation of computer-based accounting information system.

2. Perceived ease of use affects attitudes toward using on implementation of computer-based accounting information system.

3. Attitude toward using affects intention to use on implementation of computer-based accounting information system.

4. Intention to use does not affect actual usage on implementation of computer-based accounting information system.

\section{REFERENCES}

Allahyari, A., Farhad G., and Morteza R. (2012). Examine the Effect of Social Factors 
on Information Technology

Acceptance in Accounting

Profession by Using TAM Model.

Global Journal of Management and

Business Research, Vol. 12, No. 11, ISSN: 0975-5853. pp. 40-46.

Published by Global Journals Inc. (USA).

Amidu, M., John E., and Josua A. (2011). EAccounting Practices among Small and Medium Enterprises in Ghana. Journal of Management Policy and Practice vol. 12(4), pp. 146-156.

Awosejo O.J., Ajala E.B., Pretorious, P. and Zuva, T. (2013). The Role of Accounting Information Systems in Accounting Firm. International Journal of Computer Science Applications $\mathcal{E} \quad$ Information Technologies (IJCSAIT) Vol.1, No.2. pp. 21- 31.

Bugembe, J. (2010). Perceived Usefulness, Perceived Ease Of Use, Attitude And Actual Usage Of A New Financial Management System. Dissertation. Makerere University

Davis, F.D. (1989). User Acceptance of information technology: system characteristics, user perceptions and behavioral impacts. International Journal management machine studies.

Rahmana, A. (2009). Peranan Teknologi Informasi dalam Peningkatan Daya Saing Usaha Kecil Menengah. Seminar Nasional Aplikasi Teknologi Informasi. Yogyakarta.

Sriwidharmanely and Vina S. (2012). An Empirical Study of Accounting Software Acceptance among Bengkulu City Students. Asian Journal of Accounting and Governance 3. ISSN 2180-3838. pp. 99-112

Suliyanto. (2011). Ekonometrika Terapan: Teori dan Aplikasi dengen SPSS. ANDI. Yogyakarta.

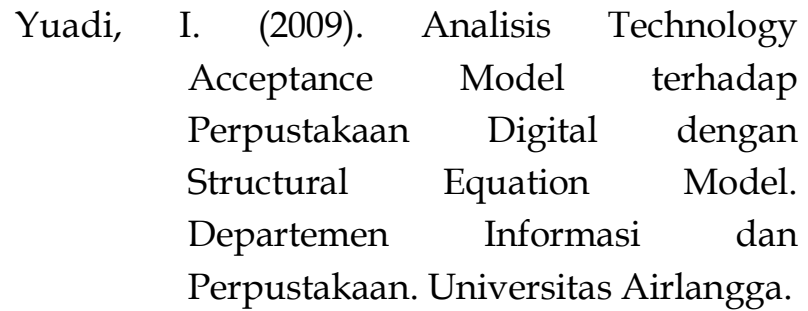

